\section{Suit to measure}

David Davies details a recent US court decision to settle a libel action involving scientists

A RECEnT decision in the United States Courts of Appeals has overturned a libel judgment against the New York Times and an officer of the National Audubon Society. A New York jury had earlier ruled as libellous accusations in the Times that certain named scientists were paid by the pesticide industry to lie by misinterpreting birdcount figures; these figures might have been relevant to the question of DDT's effect on animal life. But the appeal court ruled that the reporting was privileged under the First Amendment.

The dispute arose out of the Audubon Society's report in American Birds on its 1971 Christmas Count. The editor, Robert Arbib, wrote a foreword warning that segments of the pesticide industry and certain paid "scientist-spokesmen" were misusing bird counts to prove that bird life is thriving. He continued that apparent increases had in most cases nothing to do with real population dynamics. They were the result of ever increasing numbers of birders, better access, better knowledge and more sophisticated iden- tification. He concluded: "What we are seeing is a result of not more birds, but more birders. Any time you hear a 'scientist' say the opposite, you are in the presence of someone who is being paid to lie, or is parrotting something he knows little about".

A Times reporter, John Devlin, saw the article and asked Arbib to name some "paid liars". A.rbib turned to Roland Clement, the society's VicePresident, for help; Clement provided a list of "consistent misinterpreters" of data, adding however, "We don't have any knowledge of anyone being a paid liar". Whether this qualification was actually passed by Arbib to Devlin was strongly disputed at the original trial.

Devlin next tried to get comments from the five named-J. Gordon Edwards, Thomas Jukes, Robert WhiteStevens, Donald Spencer and Norman Borlaug. He reached White-Stevens, Jukes and Spencer, who hotly denied the charges-White-Stevens and Jukes sent copies of their publications. Devlin then wrote his story which appeared in the Times in August, 1972. It quoted the Arbib foreword extensively and added that Arbib had said in an interview that the men under attack included the five named. Devlin wrote that those he had reached "ridiculed the accusations as 'emotional', 'hysterical' and unfounded".

There was understandable alarm at the Audubon Society with the Times story, and Clement sent round an internal memo that "Arbib was trapped into listing people I have never called liars, though they may be". Clement also dispatched a letter to the Times over Arbib's signature saying "it is not simply that more birds are reported because there are more birders, but that we have more birders who are also better birders. Nor do we like to call people liars, but those who have most consistently misused our data [the five scientists were named] . . . have had time to learn from our patient explanations...".

Jukes also wrote to the Times, claiming "we have reported these figures in birds per bird watcher". Neither letter was published. Jukes, White-Stevens and Edwards sued for libel and received a total of more than $\$ 60,000$ in damages against the Times and Clement. Arbib was exonerated.

Libel actions by public figures in the United States (and the three plaintiffs were so ruled) can only succeed if it is shown that the libel was motivated by malice-that is, with knowledge that the charges were false, or with reckless disregard of whether they were false or not. The lower court apparently had no doubt that the charges were false and that insufficient care had gone

\title{
OTA's bright solar report
}

GIven relatively modest federal support, small solar energy devices could play a significant role in the United States energy picture within a decade, and their potential impact in many developing countries is even greater, according to a massive study published this week by the Congressional Office of Technology Assessment (OTA). Perhaps the most detailed report on solar technologies yet produced, OTA's 1,330-page document is likely to have a major impact on federal policy, coming as it does in the midst of Congressional debate on President Carter's energy proposals.

The report's central message is that the key factor governing the speed with which solar technologies capture the market is the relative cost of conventional energy resources. No major technological breakthroughs are needed for widespread use of solar heaters, and other technologies are also well advanced technically, the report says.

At present, solar heaters can compete economically with electrical heating systems in a limited number of situations, when the capital costs plus the lifetime fuel costs are taken into consideration. But the OTA report suggests that if electricity prices climb by a relatively modest $40 \%$ over the next quarter century, solar heaters will be economically attractive in most areas of the country by 1985 . Moreover, if $20 \%$ of the capital cost of solar heaters could be offset against income tax, they would be competitive much sooner. As for nonelectrical heating systems, the OTA report suggests that solar heaters will be cheaper than systems using synthetic gas, but will probably be more expensive than coal-fired systems at least during the next two decades.

The study is also optimistic about the potential for more exotic technologies, such as the direct conversion of solar energy to electricity by photovoltaic cells. Though such devices are now inordinately expensive, the OTA study suggests that the costs could be brought as low as $5-15$ cents per kilowatt hour within a decade. That would still be well above present electricity prices, but it may be in line with electricity prices from new generators in the late 1980s. The key, again, is the extent of incentives such as tax breaks for both purchasers and manufacturers of photovoltaic equipment, but research breakthroughs will also be required to bring down the price of photovoltaic cells.

The OTA report breaks new ground in assessing the potential impact of a large solar industry on the labour market, and its findings are likely to enhance the political prospect for solar power. Widespread production and use of small solar units would create employment in such industries as sheet metalworking and light manufacturing which are now experiencing serious unemployment problems, OTA concluded.

Since the rate of introduction of solar technologies depends critically on the relative costs of competing energy sources, solar power is likely to be particularly attractive in countries where fuel costs are high and labour costs are low. Those conditions apply in most developing countries, and thus the OTA study concludes that the potential for solar power in the third world is great. Widespread use of solar technologies would carry the added advantage of reducing international competition for dwindling fossil fuels, and it would also reduce the incentives for developing countries to purchase nuclear plants, the report notes. It is thus in the United States' political and commercial interest to foster an international market for solar technology, the report points out, and the best way to stimulate such a market is for the United States to launch its own domestic solar energy programme.

Colin Norman 